\title{
Leituras, democracia e liberdade
}

https://doi.org/10.34112/2317-0972a2016v34n66pg-10

Davina Marques ${ }^{1}$

Maria Cristina Briani ${ }^{2}$

TEMPOS DIFÍCEIS ESTES QUE NOS FORÇAM SEMPRE a pensar o nosso entorno com o coração apertado. Acabamos de reler o editorial da última edição da LTP que começava exatamente com referências a movimentos e fatos que nos chocaram e continuam chocando. É preciso continuar fazendo referência ao momento que vivemos, anunciar o vínculo existente entre o que pensamos e pesquisamos.

Uma leitura possível de nosso mundo hoje nos faz retomar um texto freireano que diz:

Não é possível refazer este país, democratizá-lo, humanizá-lo, torná-lo sério, com adolescentes brincando de matar gente, ofendendo a vida, destruindo o sonho, inviabilizando o amor.

Se a educação sozinha não transforma a sociedade, sem ela tampouco a sociedade muda. Se a nossa opção é progressista, se estamos a favor da vida e não da morte, da eqüidade e não da injustiça, do direito e não do arbítrio, da convivência com o diferente e não da sua negação, não temos outro caminho senão viver plenamente a nossa opção.

1. Instituto Federal de Educação, Ciência e Tecnologia de São Paulo, Hortolândia, SP, Brasil.

2. Pesquisadora independente, Valinhos, SP, Brasil. 
Encarná-la, diminuindo assim a distância entre o que dizemos e o que fazemos. (FREIRE, 2000, p. 67).

Freire, nesse texto, dialogava com o assassinato de Galvino Jesus dos Santos, índio Pataxó. Sua indignação ao ato e sua firme convicção na educação como movimento possível de transformação nos deixaram ali um dos seus fortes escritos.

Nós, autoras deste texto, estamos indignadas. Atravessamos um momento de temor pelas instituições democráticas, subjugadas por ações de conveniência - de novo! - nesse processo de instauração do processo de impeachment da Presidenta Dilma Rousseff. Fica aqui o registro de uma voz. Nossa revista, entendemos, que se dedica aos estudos de leitura, precisa apontar essa perspectiva.

E também porque a leitura nunca será descolada da escrita, escrevemos e damos a ler. Os textos desta LTP 66 dialogam com a filosofia, com gestos de interpretação, com práticas de leitura em sala de aula, com a história, com as tensões entre ensino de língua e de literatura. Falam também do amor pelos livros. Falam de escrita conectada a objetos. Trata-se de uma edição especial porque anuncia uma mudança significativa na nossa Leitura: Teoria e Prática. A partir deste $34^{\circ}$ ano, ela passa a ter periodicidade quadrimestral.

Apresenta-se este volume à comunidade exatamente no momento em que a Associação de Leitura do Brasil dedica-se à organização do $20^{\circ}$ Congresso de Leitura do Brasil (o $20^{\circ} \mathrm{COLE}$ ), com o tema "nas dobras do (im)possível". O evento abre-se para os processos inventivos, criativos e imaginativos da leitura; abre-se à partilha de experimentações, explorando o universo da leitura inclusive como possibilidade de alcance daquilo que ainda não é, daquilo que está em potência. Com alegria, a ALB promove mais uma vez esse grande encontro daqueles que pesquisam e promovem a leitura no Brasil.

Boas leituras!

\section{REFERÊNCIAS}

FREIRE, Paulo. Pedagogia da Indignação: cartas pedagógicas e outros escritos. São Paulo: UNESP, 2000. 